\title{
Drug Watch Deutetrabenazine
}

\section{Dr Ranjan Bhattacharyya}

Associate Professor, Department of Psychiatry, Murshidabad Medical College \& Hospital

\section{ABSTRACT}

Deutrabenazine is indicated in the management of chorea associated with Huntington's disease and in the treatment of Tardive dyskinesia in adults by US FDA. However, it should be used with a pinch of salt, as it can raise the risk of depression and suicidal thoughts with unusual behavioural abnormalities specially in patients with Huntington's disease. The family history is an added risk factor and close monitoring is required and the molecule is contraindicated in this group of patients. In hepatic impairment it is also not recommended. It shouldn't be used with Reserpine. A window period of 3 weeks after discontinuation of reserpine and 2 weeks for $\mathrm{MAO}$ inhibitors and tetrabenazine or valbenazine is recommended.

Keyword : Deutetrabenazine, VMAT2 inhibitor, Huntington's disease, Tardive dyskinesia.

Deutetrabenazine (AUSTEDO; Teva Neuroscience. Inc. AUS-41689, April 2019) is a vesicular monoamine transporter 2 (VMAT 2) inhibitor for oral administration. ${ }^{1}$ The chemical structure is shown in Figure 1. The tablet is available in following strengths $6 \mathrm{mg}$, 9 $\mathrm{mg}$ and $12 \mathrm{mg}$. The precise mechanism of action is not known but believed to be a reversible depletion of monoamines (e.g dopamine, serotonin, noradrenalines, histamines etc.) from

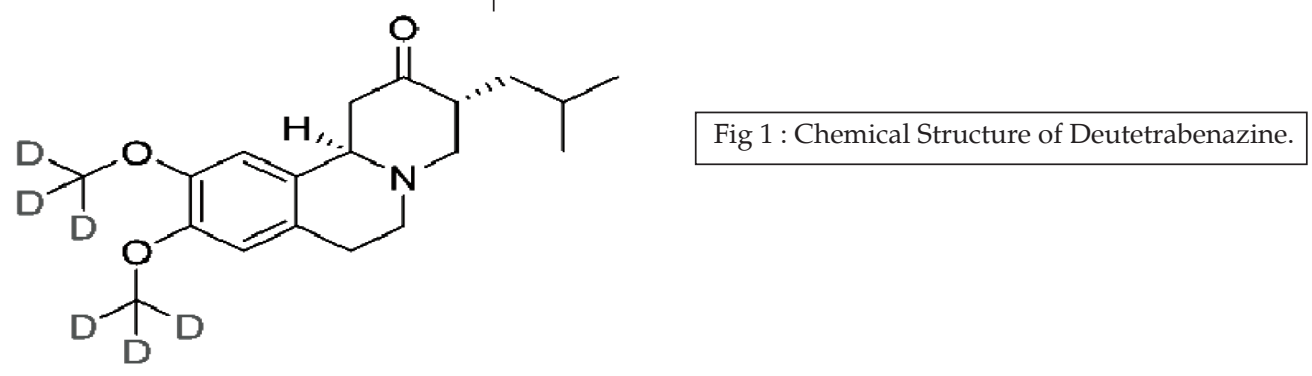

Deutetrabenazine

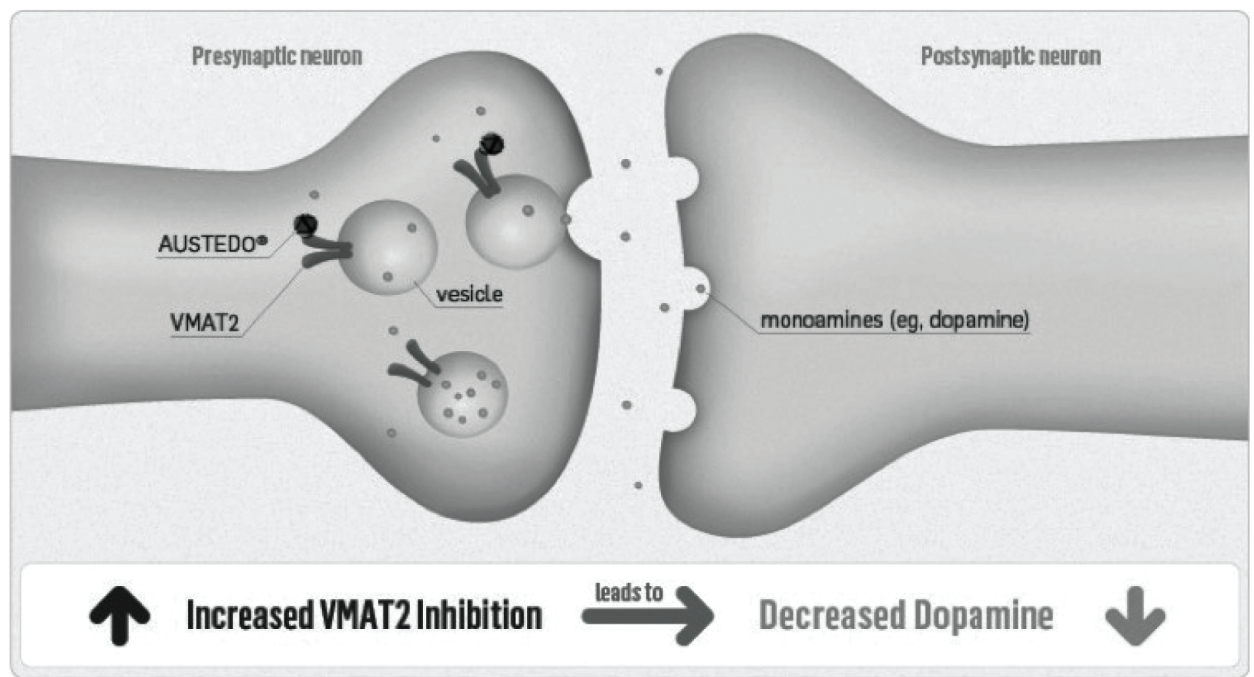

Figure 2: Melchanism of action of Deutetrabenazine. 
deutetrabenazine is a reversible inhibitor of $\mathrm{VMAT}^{2}$ resulting in decreased uptake of monoamines in the synaptic vesicles leading to depletion of monoamine stores. VMAT inhibition helps to regulate dopamine function. Some vesicular monoamine transporter 2 (VMAT2) inhibitors reduce available dopamine via alpha and/or beta metabolites that block sequestration in the presynaptic vesicle (Figure 2). 2 Unsequestered dopamine is degraded by monoamine oxidase. ${ }^{3.4}$ Reducing dopamine levels in the presynaptic neuron results in less dopamine signaling to the postsynaptic neuron, leading to fewer abnormal involuntary movements..$^{2-4}$

Pharmacodynamics : Summarized in Table 1.

\section{Table 1 : Pharmacodynamics of Deutetrabenazine}

\begin{tabular}{|l|l|}
\hline $\begin{array}{l}\text { Cardiac } \\
\text { electrophysiology }\end{array}$ & $\begin{array}{l}\text { In a DBRPCT, the } \\
\text { cardiac effect on QTc } \\
\text { interval studied of } \\
\text { a single dose 12 \& } \\
24 \text { mg respectively } \\
\text { with moxifloxacin as } \\
\text { positive control. At a } \\
\text { dose of } 24 \text { mg/d the } \\
\text { mean increase of QTc is } \\
\text { is } 4.5 \text { msec (90\% CI : 2.4 } \\
\text { 6.5 msec). }\end{array}$ \\
\hline Melanin binding & $\begin{array}{l}\text { Deutetrabenazine and } \\
\text { its active } \\
\text { metabolitesbind to } \\
\text { melanin containing } \\
\text { tissues (e.g eye, skin, } \\
\text { fur) in pigmented rats. } \\
\text { Human studies to be } \\
\text { evaluated further. }\end{array}$ \\
\hline
\end{tabular}

Pharmacokinetics : It goes extensive fast pass metabolism to active deuterated dihydrometabolites in the liver. The exposure is $40 \%$ greater in the patients with hepatic impairment. Linear dose response curve is being observed. About $80 \%$ of the molecule is absorbed. Plasma concentration of the molecule is below detection level. Peak plasma concentration (Cmax) is reached within 3-4 hours of dosing. Food has no effect with its absorption, AUC but Cmax is increased by 50\% in presence of food. It is primarily eliminated via kidney in the form of metabolites. The $\mathrm{t} 1 / 2$ of alpha and beta HTBZ combined is $9-10$ hours. The active metabolites are finally get metabolized primarily by CYP2D6 and also in insignificant way secondarily via CYP1A2, CYP3A4/5 pathways. $75-86 \%$ of deutetrabenazine is excreted in urine.

Drug interactions : (i) With CYP2D6 inhibitorsParoxetine decreases the clearance of active metabolites with increase in mean half-life. The dose adjustment is necessary to avoid adverse effects and/or toxicity. (ii) Digoxin is a substrate of P-glycoprotein. The bioavailability of digoxin was not changed when co-prescribed with tetrabenazine/ deutetrabenazine.

Summary of clinical trials : Mentioned in Table 2.

Table 2 : Summary of clinical trials of Deutetrabenazine

\begin{tabular}{|l|l|}
\hline \multicolumn{1}{|c|}{ Disease } & \multicolumn{1}{|c|}{$\begin{array}{c}\text { Summary of primary } \\
\text { outcome measures }\end{array}$} \\
\hline $\begin{array}{l}\text { 1. Chorea associated } \\
\text { with Huntington's } \\
\text { disease }\end{array}$ & $\begin{array}{l}\text { Significant reduction of } \\
\text { TMC (Total maximum } \\
\text { chorea score) score in } \\
\text { comparison to placebo } \\
\text { (P<0.0001) }\end{array}$ \\
\hline 2. Tardive dyskinesia & $\begin{array}{l}\text { Significant reduction } \\
\text { in AIMS score (Higher } \\
\text { dose 36 mg/d works } \\
\text { better than lower dose } \\
12 \text { mg/d over 12 weeks } \\
\text { (Treatment effect with } \\
95 \% \text { CI }:-1.9 \text { (-3.09, } \\
-0.79)\end{array}$ \\
\hline
\end{tabular}

Adverse effects : Most common side effects that are being observed are nasopharyngitis, insomnia, somnolence, dry mouth, fatigue, urinary tract infections, anxiety, depression, dysthymia, akathisia, agitation, restlessness constipation, confusions etc which are mostly benign.

Special populations : No adequate data on its safety in pregnancy, lactation and in paediatric or geriatric population (dose adjustment is necessary. 
Dosage and administration : Summarized in Table 3.

Table 3 : The recommended dosage guideline by USFDA.

\begin{tabular}{|l|c|c|c|}
\hline \multicolumn{1}{|c|}{ Disease } & Initial dose & Recommended dose & Maximum dose \\
\hline Chorea associated with Huntington's disease & $6 \mathrm{mg} / \mathrm{d}$ & $6-48 \mathrm{mg} / \mathrm{d}$ & $48 \mathrm{mg} / \mathrm{d}$ \\
\hline Tardive dyskinesia in adults & $12 \mathrm{mg} / \mathrm{d}$ & $12-48 \mathrm{mg} / \mathrm{d}$ & $48 \mathrm{mg} / \mathrm{d}$ \\
\hline
\end{tabular}

The dose has to be titrated at weekly intervals by $6 \mathrm{mg} / \mathrm{d}$ based on reduction of chorea and tardive dyskinesia, patient's tolerability upto a maximum tolerable dose $48 \mathrm{mg} / \mathrm{d}(24 \mathrm{mg} \mathrm{BD})$. If the total daily dose is equal or more than $12 \mathrm{mg} / \mathrm{d}$, it should be given in $\mathrm{BD}$ dose. The patients at risk should be monitored by doing an ECG before and after increasing the total dose $24 \mathrm{mg}$ or above per day.

Caution : Following cautions as summarized in Table 4 has to be maintained.

Table 4 : Cautions while prescribing Deutetrabenazine

\begin{tabular}{|l|l|l|}
\hline $\begin{array}{l}\text { 1. Depression and suicidality } \\
\text { in patients of Huntington's } \\
\text { disease(HD) }\end{array}$ & $\begin{array}{l}\text { 2. Clinical worsening of adverse } \\
\text { events in patients of HD. }\end{array}$ & 3. QTc prolongation. \\
\hline $\begin{array}{l}\text { 4. Neuroleptic malignant } \\
\text { syndrome (NMS) }\end{array}$ & $\begin{array}{l}\text { 5. Akathisia, agitation and } \\
\text { restlessness. }\end{array}$ & 6. Parkinsonism in patients of HD. \\
\hline 7. Sedation and somnolence. & 8. Hyperprolactinemia. & 9. Binding to melanin containing tissues. \\
\hline
\end{tabular}

The guideline of switching from Tetrabenazine to Deutetrabenazine is summarized on Table 5.

Table 5 : FDA recommended dose for switching from Tetrabenazine to Deutetrabenazine.

\begin{tabular}{|c|c|}
\hline Current daily dosage of Tetrabenazine & Recommended initial dose of Deutetrabenazine (AUSTEDO) \\
\hline $12.5 \mathrm{mg}$ & $6 \mathrm{mg}$ od \\
\hline $25 \mathrm{mg}$ & $6 \mathrm{mg} \mathrm{bd}$ \\
\hline $37.5 \mathrm{mg}$ & $9 \mathrm{mg} \mathrm{bd}$ \\
\hline $50 \mathrm{mg}$ & $12 \mathrm{mg} \mathrm{bd}$ \\
\hline $62.5 \mathrm{mg}$ & $15 \mathrm{mg} \mathrm{bd}$ \\
\hline $75 \mathrm{mg}$ & $18 \mathrm{mg} \mathrm{bd}$ \\
\hline $87.5 \mathrm{mg}$ & $21 \mathrm{mg} \mathrm{bd}$ \\
\hline $100 \mathrm{mg}$ & $24 \mathrm{mg} \mathrm{bd}$ \\
\hline
\end{tabular}

\section{REFERENCES}

1. https://www.austedo.com/huntingtons-chorea?gclid=Cj wKCAjw5pPnBRBJEiwAULZKvh1sTvNlf2WjOpWdlSS6e EATlaxM89WxENG_wfxjH5CZq2yvPb5-5hoCot0QAvD_ BwE \& gclsrc $=$ aw.ds last accessed on 22/05/2019.

2. AUSTEDO ${ }^{\circledR}$ (deutetrabenazine) tablets Prescribing Information. Teva Pharmaceuticals USA, Inc. August 2017.

3. Fernandez HH, Factor SA, Hauser RA, et al. Randomized controlled trial of deutetrabenazine for tardive dyskinesia : the ARM-TD study. Neurology. 2017; 88(21) : 2003-2010.

4. Data on file. Teva Neuroscience, Inc. 4. Anderson KE, Stamler $\mathrm{D}$, Davis MD, et al. Deutetrabenazine for treatment of involuntary movements in patients with tardive dyskinesia (AIM-TD) : a double-blind, randomised, placebo-controlled, phase 3 trial. Lancet Psychiatry. 2017; 4(8) : 595-604. 